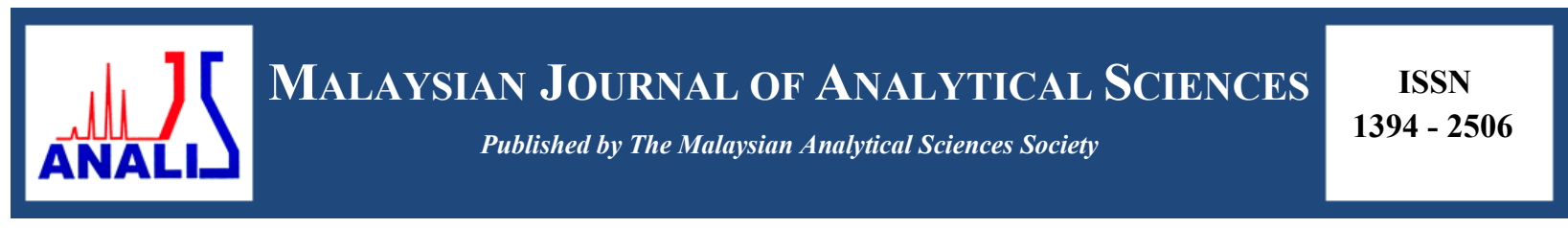

\title{
PRENYLATED DIHYDROSTILBENES FROM Macaranga heynei (EUPHORBIACEAE)
}

\section{(Dihidrostilbena Terprenil daripada Macaranga heynei (Euphorbiaceae))}

\author{
Aisyah Salihah Kamarozaman ${ }^{1,2,3 *}$, Norizan Ahmat ${ }^{2,3}$, Nur Fariza Abd Rahman ${ }^{1}$, Khong Heng Yen ${ }^{4}$ \\ ${ }^{1}$ Centre of Foundation Studies, \\ Universiti Teknologi MARA, Selangor Branch, Dengkil Campus, 43800 Dengkil, Selangor, Malaysia \\ ${ }^{2}$ Faculty of Applied Sciences, \\ Universiti Teknologi MARA, 40450 Shah Alam, Selangor, Malaysia \\ ${ }^{3}$ Atta-ur-Rahman Institute for Natural Product Discovery, \\ Universiti Teknologi MARA, Puncak Alam Campus, 42300 Bandar Puncak Alam, Selangor, Malaysia \\ ${ }^{4}$ Faculty of Applied Sciences, \\ Universiti Teknologi MARA, Sarawak Branch, Samarahan Campus, 94300 Kota Samarahan, Sarawak, Malaysia \\ *Corresponding author: aisyah2910@puncakalam.uitm.edu.my
}

Received: 4 December 2016; Accepted: 1 December 2017

\begin{abstract}
Macaranga is the largest genus in Euphorbiaceae which consists of approximately 300 species and are widely distributed in New Guinea, Borneo and from West Africa to the south Pacific islands. Phytochemical study on the leaves of Macaranga heynei has been conducted. The powder of the leaves of $M$. heynei was macerated in methanol at room temperature for 24 hours and repeated three times. The crude extract obtained was dissolved in aqueous methanol (80:20) and partitioned with hexane and ethyl acetate. The ethyl acetate crude extract was fractionated by vacuum liquid chromatography (VLC) with hexane:ethyl acetate in increasing polarity to give seven combined fractions (MH 1-7). Fraction MH 2 (1000 mg) was further purified by radial chromatography $(\mathrm{RC})$ with hexane:ethyl acetate in increasing polarity to give six combined subfractions (MH 21-26). Fraction MH $23(693.7 \mathrm{mg})$ was further purified by the same chromatographic technique but with different eluent which was chloroform:ethyl acetate in increasing polarity to afford two pure compounds (1) (10 mg) and (2) (12 mg). Based on spectroscopy analysis, the pure compounds were characterized as laevifolins A (1) and B (2).
\end{abstract}

Keywords: Laevifolin A, laevifolin B, leaves, Macaranga heynei

Abstrak

Macaranga merupakan genus terbesar dalam famili Euphorbiaceae yang mengandungi kira-kira 300 spesies dan taburannya meliputi New Guinea, Borneo dan dari Afrika Selatan ke utara kepulauan Pasifik. Kajian fitokimia ke atas daun Macaranga heynei telah dijalankan. Serbuk daun $M$. heynei direndam dalam metanol pada suhu bilik selama 24 jam dan pengesktrakan diulang sebanyak tiga kali. Ekstrak mentah yang diperolehi telah dilarutkan dalam larutan metanol (80:20) dan dipisahkan dengan heksana dan etil asetat. Etil asetat mentah difraksinasi menggunakan kromatografi cecair vakum (KCV) dengan heksana:etil asetat mengikut peningkatan kekutuban menghasilkan tujuh fraksi gabungan (MH 1-7). Fraksi MH 2 (1000 mg) selanjutnya ditulenkan dengan menggunakan kromatografi radial (RC) dengan heksana:etil asetat mengikut peningkatan kekutuban menghasilkan enam subfraksi gabungan (MH 21-26). Fraksi MH 23 (693.7 mg) seterusnya ditulenkan dengan menggunakan teknik kromatografi yang sama tetapi menggunakan eluen yang berbeza iaitu kloroform:etil asetat mengikut peningkatan kekutuban menghasilkan dua sebatian tulen (1) (10 mg) dan (2) (12 mg). Berdasarkan analisis spektroskopi, sebatian tulen tersebut dicirikan sebagai laevifolin A (1) dan B (2).

Kata kunci: Laevifolin A, laevifolin B, daun, Macaranga heynei 


\section{Introduction}

Macaranga which comprises a large genus with 300 species [1] is widely distributed in New Guinea, Borneo and from West Africa to the south Pacific islands [2]. Generally, these species are found in village-thickets, wastelands and swampy forests [3]. These species are commonly distributed in the forests as well as in disturbed areas. However, most of the species are found to be well-flourished in developed or disturbed vegetation areas compared to the natural forest [4]. Apart from being exploited as plywood and match splints, this genus is widely used for traditional remedies by the old folks. The decoction root of $M$. tanarius has been used to treat fever and as antitusive for coughing. In addition, the dried root is used as emetic agent while the fresh leaves have been used to cover wounds which act as an anti-inflammatory [5]. In Sumatra, the fruit of this species was used to improve the quality of the sugar produced while in Philippines, the bark and leaves are used in the preparation of fermented drink made from sugarcane [6].

Phytochemical studies on the species from Macaranga have shown that this genus has abundant sources of flavonoids especially prenylated flavonoids [7, 8]. In addition, this genus does contain stilbenoids, tannins, as well as terpenoids [9, 10, 11]. The flavonoid compounds isolated from Macaranga species possessed broad spectrum of pharmacological properties such as cytotoxicity, antiviral, antimicrobial as well as acetylcholinesterase activities $[12,13,14]$. Similarly, flavonoids displayed significant role in dietary antioxidant by reducing the oxidative stress in the body [15]. Meanwhile, the stilbenoids namely laevifolins A and B which were isolated from $M$. javanica possessed significant activities against $S$. aureus with MIC values $35 \mu \mathrm{M}[16]$.

M. heynei or being called as mahang biru by the locals is widely distributed in Peninsular Malaysia and Thailand. This species was found to occur on open places up to 1000 metres height as well as on exposed subsoil. M. heynei is classified by the folks as medicinal plants due to its potential in treating several illness [17]. Due to the promising bioactivities of compounds isolated from Macaranga species, M. heynei was selected for the phytochemical study.

\section{Materials and Methods}

The leaves of M. heynei was collected from Kuala Kangsar, Perak in December 2015 and the voucher specimen SK2875/15 was deposited at the herbarium of Universiti Putra Malaysia. The plant was identified by Dr. Shamsul Khamis, a botanist from Universiti Putra Malaysia.

\section{Extraction and isolation}

The leaves of $M$. heynei was dried and ground to form powder. The powder of the leaves $(2 \mathrm{~kg})$ was then macerated in methanol at room temperature. The extraction was done for 24 hours and repeated for three times. The extract was dried by using rotary evaporator to give methanolic crude extract $(300 \mathrm{~g})$. The methanolic crude extract was dissolved in the mixture of $80 \%$ methanol: $20 \%$ water followed by partition with hexane and ethyl acetate. The ethyl acetate crude extract (150 g) was fractionated by using vacuum liquid chromatography (VLC) with a mixture of hexane-ethyl acetate in increasing polarity to give seven combined fraction (MH 1-7). Fraction MH 2 (1000 mg) was further purified by radial chromatography (RC) with hexane: ethyl acetate in increasing polarity to give six combined subfractions (MH 21-26). Fraction MH 23 (693.7 mg) was further purified by the same chromatographic technique but with different eluent which was chloroform:ethyl acetate in increasing polarity to afford two pure compounds (1) (10 mg) and (2) (12 mg).

\section{Analysis}

The isolated compounds (MH 233 and MH 235) were elucidated by means of ultraviolet-visible (UV-VIS), infrared (IR), mass (MS) and one and two dimensioned nuclear magnetic resonance (NMR) spectroscopy, as well as comparison with literature data. The proton NMR was recorded in $600 \mathrm{MHz}$ while the carbon-APT NMR in 150 MHz. Chemical shift, $\delta$, ppm recorded in $\mathrm{CDCl}_{3}$.

\section{Results and Discussion}

Compound (1) as shown in Figure 1 was obtained as brownish viscous oil from the isolation of the leaves of $M$. heynei. The TOFMS in positive mode recorded a pseudo-molecular ion $[\mathrm{M}+\mathrm{H}]^{+}$peak indicated the molecular formula of $\mathrm{C}_{29} \mathrm{H}_{38} \mathrm{O}_{4}$. The UV absorptions $(\lambda 208,257 \mathrm{~nm})$ showed the characteristic of typical aromatic and 
phenol. It is supported by the IR absorptions at 3447 (O-H); 2923(alkyl); 1606 (C=C aromatic) and 1216, 1012 (ether) $\mathrm{cm}^{-1}$.The ${ }^{1} \mathrm{H}$ NMR spectrum of (1) exhibited three aromatic protons at $\delta_{\mathrm{H}} 6.75-6.31$. One singlet signal at $\delta_{\mathrm{H}} 6.31$ of aromatic proton, a doublet signal at $\delta_{\mathrm{H}} 3.34(4 \mathrm{H})$, a triplet of multiplet signal at $\delta_{\mathrm{H}} 5.10(2 \mathrm{H})$ as well as two broad singlet signals at $\delta_{\mathrm{H}} 1.80(6 \mathrm{H})$ and $1.73(6 \mathrm{H})$ showed that the aromatic proton of ring A pairs with two prenyl groups which is in symmetrical structure. Meanwhile, there are two doublet signals at $\delta_{\mathrm{H}} 6.75$ and 6.68 indicated the presence of ortho-coupled aromatic protons which pair with a prenyl group at $\delta_{\mathrm{H}} 5.12,3.39,1.80$ and 1.74 of ring B. In addition, there are two multiplet signals at $\delta_{\mathrm{H}} 2.86$ and 2.73 exhibited the presence of methylene protons which are connected to ring $\mathrm{A}$ and $\mathrm{B}$ which suggested that the compound is a dihydrostibene derivative.

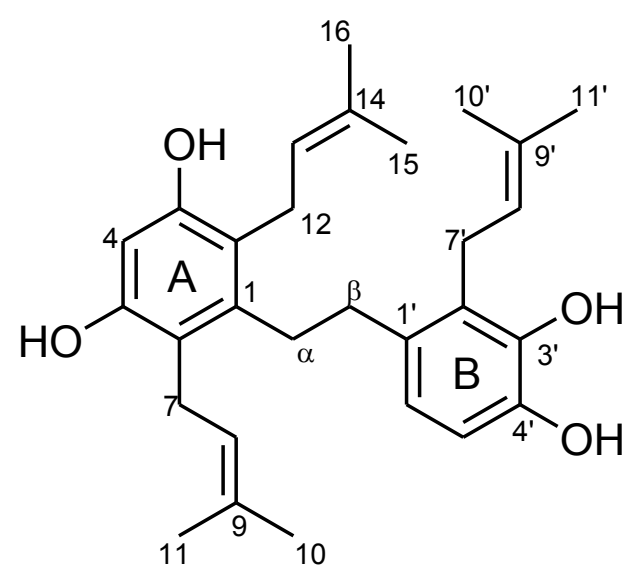

Figure 1. Chemical structure of compound (1)

The ${ }^{13} \mathrm{C}$ - APT NMR spectrum of (1) exhibited twenty two signals which represent twenty seven carbons suggested that the dihydrostilbene structure contains of four hydroxyl substituents and three phenyl groups. It was displayed by the oxyaril signals at $\delta_{\mathrm{C}} 153.5,142.4$ and 142.3 while the signals at $\delta_{\mathrm{C}} 139.7,134.6,133.8,132.2,125.9$ and 118.2 represents eight quartenary carbons. The signals at $\delta_{C} 123.0,122.1,121.1,112.8$ and 102.0 represents six methine carbons while five methylene carbons were represented by the signals at $\delta_{\mathrm{C}} 33.9,31.5,26.6,25.7$ and 25.6. Three methyl carbon was exhibited by the signals at $\delta_{\mathrm{C}} 25.8$ and 17.9.

The long range correlations between proton and carbon could be observed from HMBC spectrum .The doublet signal at $\delta_{\mathrm{H}} 3.34(4 \mathrm{H})$ showed correlation with carbon signals at $\delta_{\mathrm{C}} 139.7(\mathrm{C}-1), 118.2(\mathrm{C}-2 / 6)$ and $153.5(\mathrm{C}-3 / 5)$ which confirmed the position of two prenyl groups at C-2 and C-6 at ring A. Meanwhile, another correlation was observed between the doublet signal at $\delta_{\mathrm{H}} 3.39(2 \mathrm{H})$ with carbon signals at $\delta_{\mathrm{C}} 132.2\left(\mathrm{C}-1^{\prime}\right), 125.9\left(\mathrm{C}-2^{\prime}\right)$ and 142.3 (C-3'), confirming the position of one prenyl group at C-2' at ring B (Figure 2). The signals shown in ${ }^{1} \mathrm{H},{ }^{13} \mathrm{C}-\mathrm{APT}$ and HMBC NMR spectra are consistent with the literature [18] and characterised as laevifolin A (1).

Compound (2) as shown in Figure 3 was obtained as brownish viscous oil from the isolation of the leaves of $M$. heynei. The pseudo-molecular ion $[\mathrm{M}+\mathrm{H}]^{+}$peak indicated the molecular formula of $\mathrm{C}_{29} \mathrm{H}_{38} \mathrm{O}_{4}$. The $\mathrm{UV}$ absorptions $(\lambda 208,260 \mathrm{~nm})$ exhibited the presence of phenol and aromatic system. The IR absorptions at $3412(\mathrm{O}-\mathrm{H})$; 2923(alkyl); $1599\left(\mathrm{C}=\mathrm{C}\right.$ aromatic) and 1217, 1017 (ether) $\mathrm{cm}^{-1}$ supported the presence of phenolic system in the structure. The ${ }^{1} \mathrm{H}$ NMR spectrum of (2) is close to the compound (1) except for two doublet signal at $\delta_{\mathrm{H}} 6.61$ and 6.54 which showed the presence of meta-coupled aromatic protons in ring B. A broad singlet signal at $\delta_{\mathrm{H}} 6.31$ indicated the presence of aromatic proton in ring A. The presence of three prenyl groups was displayed by the signals at $\delta_{\mathrm{H}} 5.35-1.74$ which two of them are attached to ring A while the remaining is attached to ring $\mathrm{B}$. 


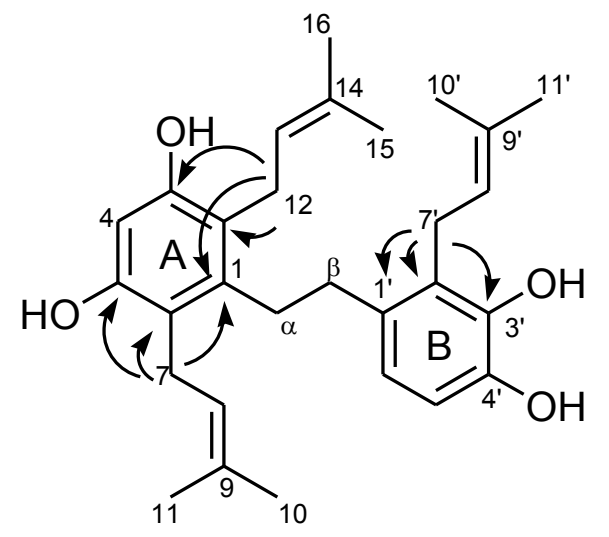

Figure 2. Selected ${ }^{1} \mathrm{H}-{ }^{13} \mathrm{C}$ HMBC found in compound (1)

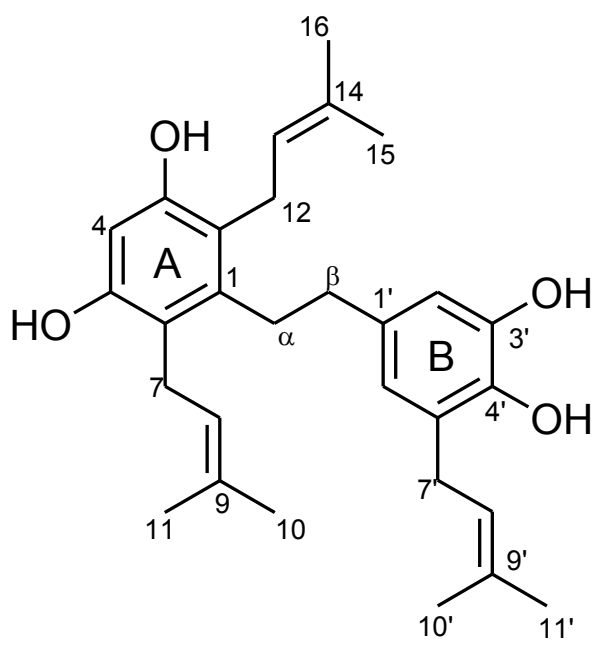

Figure 3. Chemical structure of compound (2)

The ${ }^{13} \mathrm{C}$ - APT NMR spectrum of (2) exhibited twenty two signals which represent twenty seven carbons which are similar to those shown in the spectrum of compound (1). There are four signals representing oxyaril carbons at $\delta_{\mathrm{C}}$ $153.4,153.1,143.8$ and 140.4 while five signals indicating the presence of eight quartenary carbons at $\delta_{\mathrm{C}} 139.6$, 134.2, 133.1, 127.6 and 118.2. Meanwhile, six methyne carbons were exhibited by the presence of five signals at $\delta_{\mathrm{C}}$ $123.5,122.1,121.4,113.0$ and 102.8 . The methylene carbons were represented by the signals at $\delta_{\mathrm{C}} 35.7,31.7,29.5$ and 25.2 while six methyl carbons were displayed at $\delta_{\mathrm{C}} 26.7,26.6,18.0$ and 17.9.

The long range correlations between proton and carbon could be observed from HMBC spectrum. A doublet signal of methylene protons at $\delta_{\mathrm{H}} 3.37(2 \mathrm{H})$ exhibited correlation with 140.4 (C-4'), 127.6 (C-5') and 122.1 (C-6') confirming the location of one prenyl group at C-5' at ring $\mathrm{B}$ (Figure 4). Meanwhile, the position of two prenyl groups at ring $\mathrm{A}$ are similar to that of laevifolin A (1). Based on the comparison of ${ }^{1} \mathrm{H},{ }^{13} \mathrm{C}-\mathrm{APT}$ and $\mathrm{HMBC} \mathrm{NMR}$ spectra with the literature [18], the compound was characterised as laevifolin B (2). 


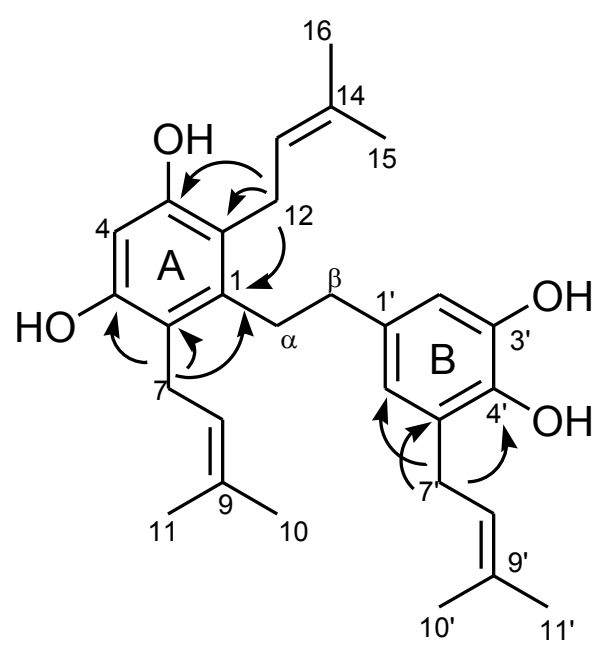

Figure 4. Selected ${ }^{1} \mathrm{H}-{ }^{13} \mathrm{C}$ HMBC found in compound (2)

\section{Conclusion}

In conclusion, the phytochemical study on the leaves of $M$. heynei has successfully isolated two prenylated dihydrostilbenes namely laevifolins A (1) and B (2). This is the first report of the compounds in this species.

\section{Acknowledgement}

I would like to express my greatest appreciation to the Ministry of Education, Malaysia for the financial support (RAGS/1/2014/SG01/UITM/4), Universiti Teknologi MARA, UiTM for providing the equipments and laboratory as well as Dr. Shamsul Khamis, a botanist from Universiti Putra Malaysia for the identification and plant collection.

\section{References}

1. Lim, T. Y., Lim, Y. Y. and Yule, C. M. (2009). Evaluation of antioxidant, antibacterial and anti-tyrosinase activities of four Macaranga species. Food Chemistry, 114: 594-599.

2. Whitmore, T. C. (1967). Studies in Macaranga, an easy genus of Malayan wayside trees. Malayan Nature Journal, 20(3): 89-99.

3. Corner, E. J. H. (1988). Wayside trees of Malaya. Malayan Nature Society, 1: pp 296-304.

4. Zakaria, R., Rosley, N. F. N., Mansor, M. and Zakaria, M. Y. (2008). The distribution of Macaranga, genus (family euphorbiaceae) in Penang Island, Peninsular Malaysia. Journal of Bioscience, 19(2): 91-99.

5. Phupattanapong, L. and Wongprasert, T. (1987) Thai medicinal plants. Part 5. Chutima: Bangkok.

6. Orwa, C., Mutua, A., Kindt, R., Jamnadass, R. and Anthony, S. (2009) Agroforestree Database: A tree reference and selection guide version 4.0 from http://www.worldagroforestry.org/sites/treedbs/ treedatabases.asp. [Access online $22^{\text {nd }}$ July 2016].

7. Sutthivaiyakit, S., Unganon,t S., Sutthivaiyaki,t P. and Suksamrarn, A. (2002). Diterpenylated and prenylated flavonoids from Macaranga denticulata. Tetrahedron, 58: 3619-3622.

8. Kumazawa, S., Murase, M., Momose, N. and Fukumoto, S. (2014). Analysis of antioxidant prenylflavonoids in different parts of Macaranga tanarius, the plant origin of Okinawan propolis. Asian Pacific Journal of Tropical Medicine, 7(1): 16-20.

9. Lin, J. H., Ishmatsu, M., Tanaka, T., Nonaka, G. and Nishioka, I. (1990). Tannins and related compounds. XCVI. Structures of macaranins and macarinins, new hydrolyzable tannis possessing macaranoyl and tergalloy ester groups from the leaves of Macaranga sinensis (BAILL.) Muell.-Arg. Chemical and. Pharmaceutical Bulletin, 3: 1844-1851.

10. Beutler, J. A., Shoemaker, R. H., Johnson, T. and Boyd, M. R. (1998). Cytotoxic geranyl stilbenes from Macaranga schweinfurthii. Journal Natural Product, 61: 1509-1512. 
11. Salah, M. A., Bedir, E., Toyang, N. J., Khan, I. A., Harries, M. D. and Wedge, D. E. (2003). Antifungal clerodane diterpenes from Macaranga monandra (L) Muell. et Arg. (Euphorbiaceae). Journal of Agricultural and Food Chemistry, 51(26): 7607-7610.

12. Shinji, F., Kanki, K., Yukinori, M., Tsuyoshi, T. and Shigeo, N. (1995). Cytocidal and antimicrobial activities of flavonoids. Natural Medicines, 49(3): 322-328.

13. Orhan, D. D., Ozcelik, B., Ozgen, S. and Ergun, F. (2010). Antibacterial, antifungal and antiviral activities of some flavonoids. Microbiological Research, 165: 496-504.

14. Jianguo, C., Xian, X., Xiling, D., Jianbo, X., Quanxi, W., Andrae-Marobela, K. and Okatch, H. (2013). Flavonoids profiles, antioxidant, acetylcholinesterase inhibition activities of extract from Dryoathyrium boryanum (Willd.) Ching. Food and Chemical Toxicology, 55: 121-128.

15. Das, S., Mitra, I., Batuta, S., Alam, M. N., Roy, K. and Begum, N. A. (2014). Design, synthesis and exploring the quantitative structure-activity relationship of some antioxidant flavonoid analogues. Bioorganic \& Medicinal Chemistry Letters, 24(21): 5050-5054.

16. Ilmiawati, A., Hakim, E. H. and Syah, Y. M. (2015). Prenylated 9,10-dihydrophenanthrenes from Macaranga javanica. Zeitschrift für Naturforschung B, 70(9): 659-663.

17. Jansen, P. C. M., Westphal, E. and Wulijarni-Soetjipto, N. (1997). PROSEA: Plant resources of south-east asia 11, Auxiliary Plants. LIPI Press: Jakarta.

18. Ahmat, N., Said, I. M., Latip, J., Din, L. B., Syah, Y. M. and Hakim, E. H. (2007). New prenylated dihydrostilbenes from Croton laevifolius. Natural Product Communications, 2(11): 1137-1140. 